MUQODDIMAH

\title{
PERSEPSI MASYARAKAT TERHADAP PEMBANGUNAN DI DESA MUARA BOTUNG KECAMATAN KOTANOPAN KABUPATEN MANDAILING NATAL TAHUN 2015
}

\author{
Ali Sahbana \\ Universitas Muhammadiyah Tapanuli Selatan, \\ Email : ali.syahbana@um-tapsel.ac.id
}

\begin{abstract}
Abstrak
Pembangunan desa memegang peranan yang penting karena merupakan bagian yang tidak terpisahkan dan pada hakikatnya bersinergi terhadap pembangunan daerah dan nasional. Hal tersebut terlihat melalui banyaknya program pembangunan yang di rancang pemerintah untuk pembangunan desa. Karenanya dapat dipastikan apapun bentuk setiap program pembangunan dari pemerintah akan selalu bermuara ke desa. Hampir seluruh instansi terutama pemerintah daerah akomodasi pembangunan desa dalam program kerjanya. Tentunya berlandaskan pemahaman bahwa desa sebagai kesatuan geografis terdepan yang merupakan tempat sebagian besar penduduk bermukim.

Tujuan penelitian ini adalah untuk mengetahui bagaimana pembangunan rabat beton usaha tani di Desa Muara Botung Kecamatan Kotanopan Kabupaten Mandailing Natal dan untuk mengetahui persepsi masyarakat terhadap pembangunan rabat beton usaha tani di Desa Muara Botung Kecamatan Kotanopan Kabupaten Mandailing Natal. Adapun jenis penelitian yang digunakan adalah metode penelitian deskriptif dengan pendekatan analisis deskriptif kuanlitatif.

Adapun yang menjadi hipotesis penelitian ini adalah "Persepsi Masyarakat terhadap Pembangunan Rabat Beton Usaha Tani di Desa Muara Botung Kecamatan Kotanopan Kabupaten Mandailing Natal tidak baik."
\end{abstract}

Kata Kunci : Fungsi, Manfaat, Jenis Tanah

\section{PENDAHULUAN}

Pembangunan adalah "suatu rencana yang tersusun secara rapi yang sistematik dan rasional dari berbagai sarana dan prasarana kerja yang sifatnya terbatas untuk memperoleh hasil yang maksimal".(afifuddin,2012:76)

Rencana pembangunan daerah harus disusun berdasarkan potensi yang dimiliki dan kondisi yang ada sekarang, kondisi yang ada itu meliputi modal, sumber daya alam, sumber daya manusia, sarana dan prasarana pembangunan, teknologi, aspirasi, masyarakat setempat dan lainnya.

Karena dana atau anggaran pembangunan yang tersedia terbatas, sedangkan program pembangunan yang di butuhkan relatif banyak, maka perlu dilakukan :

1. Penentuan prioritas program pembangunan yang diusulkan itu, yang disusun berdasarkan kriteria yang terukur.
2. Peningkaan partisipasi masyarakat untuk menunjang implementasi program pembangunan tersebut.(Rahardjo Adisasmita,2006:34)

Pembangunan desa memegang peranan yang penting karena merupakan bagian yang tidak terpisahkan dan pada hakikatnya bersinergi terhadap pembangunan daerah dan nasional. Hal tersebut terlihat melalui banyaknya program pembangunan yang di rancang pemerintah untuk pembangunan desa. Dalam struktur pemerintahan, desa menempati posisi terbawah, akan tetapi justru terdepan dan langsung berada di tengah masyarakat. Karenanya dapat dipastikan apapun bentuk setiap program pembangunan dari pemerintah akan selalu bermuara ke desa. Hampir seluruh instansi terutama pemerintah daerah akomodasi pembangunan desa dalam program kerjanya. Tentunya berlandaskan pemahaman bahwa desa sebagai kesatuan 
geografis terdepan yang merupakan tempat sebagian besar penduduk bermukim.

Tingkat partisipasi dalam pembangunan masih terbatas, misalnya masih sebatas peran serta fisik tanpa berperan secara luas sejak perencanaan sampai evaluasi. Dikarenakan masyarakat belum diikut sertakan dalam perencanaan dan evaluasi ini dikarenakan masyarakat menilai itu merupakan tugas pemerintah. Pemerintah berperan dominan sejak dari perencanaan hingga pelaksanaan program pembangunan.

Masih minimnya prasarana sosial ekonomi serta penyebaran jumlah tenaga kerja produktif yang tidak seimbang, termasuk tingkat produktivitas, tingkat pendapatan masyarakat dan tingkat pendidikan yang relatif masih rendah. Semua itu pada akhirnya berkontribusi pada kemiskinan penduduk.

Untuk mewujudkan pemberdayaan masyarakat di desa pada dasarnya dipengaruhi oleh banyak faktor, diantaranya adalah dana yang dimiliki oleh desa, tingkat pendidikan masyarakat, tingkat perekonomian masyarakat, kesadaran masyarakat, peran serta masyarakat, sumber daya alam yang tersedia, kondisi sosial masyarakat, kemandirian masyarakat, peningkatan prakarsa dan swadaya masyarakat dan lain sebagainya.

Dalam RAPBDES tahun 2015 pembangunan di Desa Muara Botung bidang pelaksanaan pembangunan desa sebesar Rp. 185.601.000,- meliputi tembok penahan tanah, rehab rabat beton dan rabat beton usaha tani melewati tanah masyarakat. Pembangunan rabat beton usaha tani di Desa Muara Botung Kecamatan Kotanopan Kabupaten Mandailing Natal telah direncanakan melewati persawahan Saba Gonting Jae ini diperkirakan akan lebih menghemat jarak tempuh, waktu dan efisiensi pengangkutan hasil usaha tani. Pembangunan yang dibuat ada masyarakat yang tidak setuju melalui tanahnya, sehingga rabat beton usaha tani dipindahkan ke lokasi tanah masyarakat yang lain tetapi menjadi berliku-liku.

Berdasarkan pembangunan rabat beton tersebut menyebabkan perbedaan pendapat di masyarakat, baik masyarakat yang sawahnya di Saba Gonting Jae maupun Saba Gonting Julu, tidak hanya itu perbedaan pendapat juga terjadi di kalangan Badan Permusyawaratan Desa, Sekretaris Desa dan Tokoh Masyarakat.

Berdasarkan penjelasan di atas maka penulis tertarik untuk melakukan penelitian tentang "Persepsi Masyarakat terhadap Pembangunan di Desa Muara Botung Kecamatan Kotanopan Kabupaten Mandailing Natal Tahun 2015."

\section{Rumusan Masalah}

Berdasarkan latar belakang di atas, maka rumusan masalah yang akan diteliti oleh penulis adalah:

1. Bagaimana pembangunan rabat beton usaha tani di Desa Muara Botung Kecamatan Kotanopan Kabupaten Mandailing Natal?

2. Bagaimana persepsi masyarakat terhadap pembangunan rabat beton usaha tani di Desa Muara Botung Kecamatan Kotanopan Kabupaten Mandailing Natal?

\section{Tujuan Penelitian}

Tujuan dari penelitian ini adalah:

1. Untuk mengetahui bagaimana pembangunan rabat beton usaha tani di Desa Muara Botung Kecamatan Kotanopan Kabupaten Mandailing Natal.

2. Untuk mengetahui persepsi masyarakat terhadap pembangunan rabat beton usaha tani di Desa Muara Botung Kecamatan Kotanopan Kabupaten Mandailing Natal.

\section{Manfaat Penelitian}

Hasil penelitian ini di harapkan memiliki manfaat sebagai berikut :

1. Bagi Penulis

Manfaat yang diperoleh adalah sebagai bahan untuk menambah pengetahuan tentang pembangunan di Desa Muara Botung Kecamatan Kotanopan Kabupaten Mandailing Natal dan menjadi masukan bagi penulis lainnya dalam mengembangkan penelitian sejenak.

2. Bagi Masyarakat 
Hasil penelitian ini diharapkan dapat memberikan masukan atau rujukan yang bermanfaat sehingga dapat meningkatkan kesejahteraan masyarakat yang lebih baik, serta diharapkan dapat menjadi motivasi bagi masyarakat dalam pembangunan desa berikutnya.

\section{METODE PENELITIAN Jenis Penelitian}

Jenis penelitian yang digunakan dalam penelitian ini adalah metode penelitian deskriptif dengan pendekatan analisis deskriptif kuantitatif untuk mengolah data-data yang diperoleh dari lokasi penelitian.

Penelitian pendekatan kuantitatif adalah untuk mengolah data-data yang diperoleh dari lokasi penelitian, dimana menurut Sugiyono mengatakan "Pendekatan Kuantitatif yaitu metode penelitian yang berlandaskan pada filsafat positivisme, digunakan untuk meneliti pada populasi atau sampel tertentu, pengumpulan data menggunakan instrumen penelitian, analisis data bersifat kuantitatif/statistik, dengan tujuan untuk menguji hipotesis yang telah ditetapkan.(Sugiono,2008:8)

\section{Populasi dan Sampel Populasi}

Populasi adalah seluruh subjek penelitian ditetapkan untuk ditarik kesimpulannya. Suharsimi Arikunto mengemukakan bahwa "Populasi adalah keseluruhan subjek penelitian.(Suharsimi Arikunto,2010:173)

Sedangkan Abdurrahmat Fathoni mengatakan bahwa "Populasi adalah keseluruhan unit elementer yang parameternya akan diduga melalui statistika hasil analisis yang dilakukan terhadap sampel penelitian.( Abdurrahmat Fathoni,2011:103)

Sugiyono mendefenisikan bahwa: "Populasi adalah wilayah generalisasi yang terdiri atas obyek/subyek yang mempunyai kualitas dan karakteristik tertentu yang ditetapkan oleh peneliti untuk dipelajari dan kemudian ditarik kesimpulannya.(Suharsimi Arikunto,2010:90)
Dari pendapat di atas dapat diambil kesimpulan bahwa populasi adalah seluruh subjek penelitian ditetapkan untuk ditarik kesimpulannya. Populasi dalam penelitian ini menurut defenisi di atas yang ditentukan oleh karakterisktik tertentu adalah masyarakat Desa Muara Botung yang diambil berdasarkan Kepala Keluarga sebanyak 223.

\section{Sampel}

Sampel adalah sebagian dari jumlah dan karakterisktik yang dimiliki oleh populasi tersebut. Menurut Sugiyono Sampel adalah: "Bagian dari jumlah dan karakteristik yang dimiliki oleh populasi tersebut. (Sugiono,2009:85)

Sedangkan Beni Ahmad Saebani mengatakan bahawa "Sampel adalah bagian dari populasi. (Beni Ahmad Saebani dan Kadar Nurjaman:60)

Dari definisi di atas, penulis menyimpulkan bahwa sampel adalah bagian dari populasi yang memiliki karakteristik yang sama. Dengan demikian sampel bisa diambil dari bagian populasi. Sebagaimana pendapat Suharsimi Arikunto mengatakan "apabila subjeknya kurang dari 100 , lebih baik diambil semua sehingga penelitiannya merupakan penelitian populasi. Selanjutnya jika jumlah subjeknya lebih besar dari 100, maka dapat diambil antara $10-15 \%$ atau $20-25 \%$ atau lebih. (Suharsimi Arikunto,2010:134)

Berdasarkan kutipan diatas maka penulis merumuskan sampel dengan menggunakan Random Sampling (sampel acak) sebagai berikut:

$\mathrm{N}=223$

$=223 \times 20 \%=44,6$ dibulatkan menjadi 45 kepala keluarga

Dari perhitungan yang diperoleh maka sampel dalam penelitian ini berjumlah 45 kepala keluarga.

\section{Defenisi Konsep dan Defenisi Operasional Defenisi Konsep}

Untuk mengetahui persepsi masyarakat terhadap pembangunan di Desa Muara Botung Kecamatan Kotanopan Kabupaten Mandailing Natal, 
tentunya diperlukan konsep yang relepan, yaitu:

1. Persepsi merupakan proses pengolahan informasi dari lingkungan yang berupa stimulus, yang diterima melalui alat indera dan diteruskan keotak untuk diseleksi, diorganisasikan sehingga menimbulkan penafsiran atau penginterpretasikan yang berupa penilaian dari penginderaan atau pengalaman sebelumnya

2. Masyarakat adalah kelompok manusia yang sedikit banyak memiliki kebebasan dan bersipat kekal, yang menempati suatu kawasan, memiliki kebudayaan, dan memiliki hubungan dalam kelompok yang bersangkutan.

3. Pembangunan adalah suatu usaha atau proses perubahan, demi tercapainya tingkat kesejahteraan atau mutu-hidup suatu masyarakat serta individu-individu di dalamnya yang berkehendak dan melaksanakan pembangunan itu.

4. Rabat beton adalah pengecoran beton biasa yang sering diaplikasikan sebagai lantai dasar dengan sistem pengecoran yang asal jadi, Akan tetapi jika rabat beton ini diaplikasikan dengan cara yang tepat dan finishing yang rapi akan terlihat bagus dan mempunyai kekuatan yang sangat baik pula.

5. Desa adalah kesatuan masyarakat hukum yang memiliki batas-batas wilayah yang berwenang untuk mengatur dan mengurus kepentingan masyarakat setempat, berdasarkan asal-usul dan adat istiadat setempat yang diakui dan dihormati dalam sistem pemerintahan Negara Kesatuan Republik Indonesia.

\section{Defenisi Operasinal}

Defenisi operasional merupakan gambaran teliti mengenai prosedur yang diperlukan untuk memasukkan unit-unit dalam kategori dari tiap-tiap variabel.

Variabel adalah yang secara empiris dapat diukur dan dinilai. Dalam penelitian ini terdapat dua variabel yaitu:
1. Variabel bebas (variabel X), pembangunan rabat beton

Variabel bebas (X) merupakan" variabel yang mempengaruhi atau yang menjadi sebab perubahannya atau timbulnya variabel terikat. (Suharsimi Arikunto,2010:39)

Dari pengertian diatas maka variabel bebes dalam penelitian ini adalah pembangunan rabat beton dengan indikator:

a. Fungsi. diperuntukkan untuk apa rabat beton.

b. Manfaat, sejauh mana kegunaan rabat beton dibuat.

c. Jenis tanah, tanah yang dilalui rabat beton strukturnya keras, lunak.

d. Posisi, tanahnya kondisi posisinya seperti terjal, miring, dan datar.

2. Variabel terikat (variabel $\mathrm{Y}$ ), persepsi masyarakat

Variabel terikat $(Y)$ "merupakan yang dipengaruhi atau yang menjadi akibat karena variabel bebas". (Suharsimi Arikunto,2010:39) Dari pengertian diatas maka variabel terikat dalam penelitian ini adalah persepsi masyarakat dengan indikator:

a. Situmulus adalah bagian dari respon stimuli yang berhubungan dengan kelakuan.

b. Registrasi adalah sebuah pendaftaran setiap program yang berfungsi untuk menghubungkan data pribadi di pogram tersebut.

c. Interpretasi adalah proses subjektif dari menjelaskan persepsi kedalam cara yang kita mengerti

Sebagai pelengkap dalam pembahasan ini maka diperlukan adanya data atau informasi baik dari dalam perusahaan maupun dari luar perusahaan. Penulis memperoleh data yang berhubungan dengan menggunakan metode sebagai berikut:

1. Data Primer, diperoleh melalui:

a. Observasi, yaitu pengumpulan data dengan pengamatan langsung kepada objek penelitian serta melakukan pencatatan yang dianggap relevan dengan penelitian.

b. Angket yaitu merupakan suatu pengumpulan data dengan 
memberikan atau menyebarkan daftar pertanyan atau pernyataan kepada responden dengan harapan memberikan respons atas daftar pertanyaan tersebut. Angket digunakan untuk memperoleh data mengenai persepsi masyarakat terhadap pembangunan rabat beton usaha tani.

2. Data Sekunder, diperoleh melalui:

a. Penelitian Kepustakaan, teknik yang dilakukan dengan cara membaca, mempelajari, mengutip, dan merangkum data yang berkaitan dengan permasalahan yang akan diteliti.

b. Studi dokumentasi, cara ini dilakukan dengan jalan melakukan pendahuluan terhadap catatan tertulis yang ada di lokasi penelitian.

\section{Teknik Analisis Data}

Data yang berasal dari hasil penelitian dengan menggunakan angket dan studi dokumentasi kemudian dianalisis menggunakan statistik yaitu hasil jawaban responden. Selanjutnya data dianalisis dengan menggunakan skala likert yaitu setiap jawaban diberi nilai skor sebagai berikut:

1. Sangat Baik diberi skor 5

2. Baik diberi skor 4

3. Cukup Baik diberi skor 3

4. Tidak Baik diberi skor 2

5. Sangat Tidak Baik diberi skor 1

Dimana, jumlah skor tertinggi adalah 5 kali jumlah responden dan jumlah skor terrendah adalah 1 kali jumlah responden.

\section{PEMBAHASAN}

Hipotesis adalah pengajuan jawaban sementara atas masalah yang terdapat dalam penelitian. Hipotesis yang penulis tetapkan dalam penelitian ini akan dilakukan pengujian untuk membuktikan diterima atau ditolak. Setelah penulis memperoleh data tentang kedua variabel, maka langkah selanjutnya penulis akan melakukan analisis data tersebut untuk menguji hipotesis.

Untuk melakukan pengujian hipotesis dalam penelitian ini, penulis menggunakan teknik korelasi Product Moment yaitu:

$$
r_{x y}=\frac{N \sum X Y-\left(\sum X\right)\left(\sum Y\right)}{\sqrt{\left\{N \sum X^{2}-\left(\sum X\right)^{2}\right\}\left\{N \sum Y^{2}-\left(\sum Y\right)^{2}\right\}}}
$$

Keterangan:

$\mathrm{N} \quad=$ Jumlah Sampel

$\Sigma X Y=$ Jumlah hasil perkalian antara skor $X$ dan skor $Y$

$\sum X \quad=$ Jumlah seluruh skor $X$

$\sum Y \quad=$ Jumlah seluruh skor $Y$.

Dengan demikian diperoleh $r_{\text {hitung }}$ sebesar 0,793 sementara $r_{\text {tabel }}$ dengan taraf kepercayaan $95 \%$ diperoleh nilai sebesar 0,294 . Dengan demikian persepsi masyarakat terhadap pembangunan rabat beton usaha tani di Desa Muara Botung Kecamatan Kotanopan Kabupaten Mandailing Natal tidak baik diterima kebenarannya.

\section{Koefisien Uji Signifikan}

Untuk mengetahui hubungan antara variabel itu signifikan atau tidak, dapat dilakukan dengan cara perhitungan uji $r$, dimana hasil perhitungan diperoleh $r_{\text {hitung }}$ sebesar 0,793 , sementara $r_{\text {tabel }}$ dengan taraf kepercayaan $95 \%$ diperoleh pada tabel "r" Product Moment nilai sebesar 0,294 . Maka $r_{\text {hitumg }}>r_{\text {tabel }}$ yaitu $0,793>$ 0,294 , berarati bahwa korelasi antara variabel $x$ (pembangunan rabat beton) dengan variabel y (persepsi masyarakat) adalah signifikan. Artinya variabel $\mathrm{x}$ sangat berpengaruh terhadap variabel $y$.

\section{Uji Determinasi}

Sedangkan untuk mengetahui besarnya persentase persepsi masyarakat terhadap pembangunan rabat beton di Desa Muara Botung Kecamatan Kotanopan Kabupaten Mandailing Natal maka diuji dengan rumus:

$$
\begin{aligned}
D & =\left(r_{x y}\right)^{2} \times 100 \% \\
& =(0.793)^{2} \times 100 \% \\
& =0,629 \times 100 \% \\
& =63 \%
\end{aligned}
$$

Berdasarkan hasil perhitungan di atas dapat diketahui 63\%, Dengan demikian determinasi persepsi masyarakat terhadap pembangunan rabat beton di 
Desa Muara Botung Kecamatan Kotanopan Kabupaten Mandailing Natal.

\section{SIMPULAN DAN SARAN}

Adapun kesimpulan yang dapat penulis peroleh dari hasil penelitian mengenai persepsi masyarakat terhadap pembangunan rabat beton di Desa Muara Botung Kecamatan Kotanopan Kabupaten Mandailing Natal yang telah penulis uraikan pada bab sebelumnya adalah:

1. Pembangunan rabat beton usaha tani di Desa Muara Botung Kecamatan Kotanopan Kabupaten Mandailing Natal diterima oleh masyarakat dengan baik hal ini terbukti dari hasil penelitian

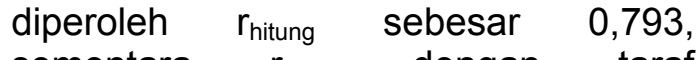
sementara $r_{\text {tabel }}$ dengan taraf kepercayaan $95 \%$ diperoleh pada tabel "r" Product Moment nilai sebesar 0,294. Maka $r_{\text {hitumg }}>r_{\text {tabel }}$ yaitu 0,793 $>0,294$, berarati bahwa korelasi antara variabel $x$ (pembangunan rabat beton) dengan variabel y (persepsi masyarakat) adalah signifikan.

2. Persepsi masyarakat terhadap pembangunan rabat beton usaha tani di Desa Muara Botung Kecamatan Kotanopan Kabupaten Mandailing Natal cukup baik.

Berdasarkan kesimpulan tersebut di atas, maka saran yang penulis sampaikan dalam penelitian ini adalah:

1. Bagi Pemerintah Desa

Agar lebih memamfaatkan alokasi dana sehingga pembangunan dapat berjalan sehingga kemajuan dan perkembangan desa Muara Botung Kecamatan Kotanopan Kabupaten Mandailing Natal dan lebih dinikmati oleh masyarakat.

2. Bagi Masyarakat

Agar memamfaatkan jalan rabat beton di Desa Muara Botung Kecamatan Kotanopan Kabupaten Mandailing Natal sehingga dapat meningkatkan kesejahteraan.

\section{DAFTAR PUSTAKA}

Adisasmita, Rahardjo. 2005. Dasar-dasar Ekonomi Wilayah. Yogyakarta: Graha IImu.
2006.

Pembangunan Pedesaan dan Perkotaan. Yogyakarta: Graha IImu.

Afifuddin. 2012. Pengantar Administrasi Pembangunan Konsep. Teori dan Implikasinya di Era Reformasi. Bandung: Alfabeta.

Ahmadi, Abu. Ilmu Sosial Dasar. Rineka Cipta. Jakarta. 2009.

Arikunto, Suharsimi. 2006. Prosedur Penelitian Suatu Pendekatan Praktik, Jakarta: PT. Rineka Cipta.

\section{Prosedur} Penelitian Suatu Pendekatan Praktik. Jakarta: Rineka Cipta.

Fathoni, Abdurrahmat. 2011. Metode Penelitian \& Teknik Penyusunan Skripsi. Jakarta: Rineka Cipta.

Sugiyono. 2009. Metode Penelitian Kualitatif. Kualitatif. dan $R \& D$. Bandung: Alfabeta.

Wasistiono, Sadu. \& Irwan Tohir. 2007. Prospek Pengembangan Desa. Bandung: Fokusmedia.

Pembukaan Undang-Undang Dasar Negara Republik Indonesia 1945.

Undang-Undang Nomor 06 Tahun 2014 Tentang Desa. 